\title{
A idea de Comunidade universal em Francisco Suárez *
}

\author{
The idea of universal community in Francisco Suárez
}

Pedro Calafate

\begin{abstract}
Resumo: Estudamos o modo como Suárez aprofundou uma tradição decisiva para fortalecer a ideia de comunidade universal de natureza supraestatal, assente em regras morais superiores à soberania dos estados, tendo como fundamento a dignidade da pessoa humana, a unidade do género humano, o bem comum universal e a igualdade natural das soberanias do orbe, tanto do ponto de vista do domínio de jurisdição como no de propriedade, suportada por conceções democráticas sobre a origem do poder civil. Visava-se, assim, um conceito de comunidade não meramente internacional, mas propriamente universal, ao mesmo tempo que se proclamava a legitimidade das soberanias indígenas no Novo Mundo, porque o poder civil não radicava na fé ou na caridade mas sim na razão natural e na sociabilidade dos homens.
\end{abstract}

Palabras Clave: Estado, Humanidade, Lei Natural, Direito das Gentes, Paz

Abstract: We study how Suárez deepened a tradition decisive to strengthen the idea of universal community of supra-state nature, based on moral rules superior to the sovereignty of the states, on the dignity of the human person, on the unit of the Human genre,

\footnotetext{
* Este estudo foi elaborado com o apoio da FCT: Fundação para a Ciência e a Tecnologia-IP (Portugal), no âmbito do projeto "De Restitutione: a Escola Ibérica da Paz e a Ideia de Justiça na Ocupação da América (século XVI), PTDC/MHC-FIL/467172014.

** Universidade de Lisboa / Faculdade de Letras. E-mail: pedrocalafate@ hotmail.com
} 
on the universal common good and natural equality of the sovereigns of the world, both from the point of view of the domain of jurisdiction and of the property, supported by democratic conceptions about the origin of civil power. A concept of a community not only international but universal was thus affirmed, while the legitimacy of indigenous sovereignties in the New World was undermined, because civil power did not lie in faith or charity, but in natural reason and in sociability of men.

Key words: State, Humanity, Natural Law, Law of Nations, Peace

Recibido: 6 de junio de 2017.

Evaluado: 28 de junio de 2017. 


\section{Considerações Preliminares}

Num expressivo e influente livro sobre a filosofia política do século XX, Hannah Arendt sublinhou que a fonte mais ativa das experiências totalitárias dos últimos duzentos anos foi a negação da ideia de Humanidade como conceito regulador da lei internacional (Arendt, 2011, p. 205).

Tal exclusão alicerçou-se, no período moderno, em conceções filosóficas como as de Thomas Hobbes e Maquiavel. O primeiro, ao entender a criação do estado social como superação do estado de natureza, caracterizado pela guerra (natural) de todos contra todos, ao mesmo tempo que excluía a política estrangeira do contrato humano. $\mathrm{O}$ segundo, ao excluir também da sua obra a consideração da perspetiva supranacional do problema do Estado.

Nestes termos, o conceito de humanidade, aperfeiçoado pela moral estoica e cristã (Truyol e Serra, 1958), cedeu lugar a uma cada vez mais acentuada conceção das nações como meras tribos, separadas por natureza, guiando-se por instintos de conservação "e ignorantes dos princípios da solidariedade humana" (Arendt, 2011, p. 205).

Nos dois casos vingou uma conceção da vida política internacional regulada pelo equilíbrio instável entre egoísmos, impondo uma lógica imanente ao mundo político sem relação com regras morais superiores ao jogo dos interesses e das hegemonias, acabando por converter o estado, sobretudo a partir de E. Vattel, em sujeito único do direito internacional, com exclusão dos indivíduos e das comunidades organizadas em termos distintos do das soberanias estatais europeias, consagradas em Vestefália (1648).

Assim se foi abrindo caminho para um direito internacional marcado pelo voluntarismo estatal ilimitado, gerando a permissividade do recurso à guerra, a celebração de tratados desiguais, a diplomacia secreta, as zonas de influência e a desigualdade entre os estados, com expressão no imperialismo totalitário e na hecatombe das duas guerras mundiais do século XX.

Foi essa a conceção clássica do direito internacional vigente até à segunda guerra mundial: a de um jus intergentes fragmentário, protegido pelo consentimento, baseado na vontade soberana dos estados "que não conhece legislador nem juiz nem sanção, fora do quadro do consentimento estadual” (Guerra, 2013, p. 83).

\section{A Dignidade da Pessoa Humana e a Razão de Humanidade}

Em sentido diferente, nas universidades da Península Ibérica, ao longo da idade moderna e antes de Grócio, afirmou-se uma tradição teológica e ético-jurídica decisiva para equacionar e fortalecer a ideia de comunidade universal de natureza supraestatal, assente em regras morais superiores à soberania dos estados, tendo como fundamento a dignidade da pessoa humana, a unidade do género humano, o bem comum universal, a igualdade natural das soberanias do orbe, tanto do ponto de vista do domínio de jurisdição como no de propriedade, suportada por conceções democráticas ${ }^{1}$ sobre a

\footnotetext{
${ }^{1}$ Diz Suárez: “A democracia poderia existir sem uma instituição positiva, apenas por instituição ou dimanação natural, com a negação apenas de uma instituição nova ou positiva, pois a própria razão
}

50 Pedro Calafate. A idea de Comunidade universal em Francisco Suárez ... 48-65. 
origem do poder civil, independentemente das formas de governo, por dizerem respeito ao arbítrio dos povos.

A ideia de comunidade universal teorizada nas universidades ibéricas do renascimento, de Francisco de Vitoria a Francisco Suárez, fortemente impulsionada pelos desafios da primeira globalização patrocinada por Espanha e Portugal, pressupunha a existência de valores universais, bem como de direitos e deveres emanados diretamente dos direitos natural e das gentes que a todos vinculavam, -- os estados, os povos e os seres humanos.

Visava-se, assim, um conceito de comunidade não meramente internacional, mas propriamente universal, com base numa ordem que não radicava na estrita vontade dos estados nem era por eles voluntariamente criada, embora fosse por sua vontade que a ela aderiam e respeitavam os seus ditames, afastadas que estavam as teses medievais sobre a autoridade universal do imperador ou do Papa.

De facto, a comunidade universal, para os teólogos renascentistas de Salamanca, Coimbra e Évora, e, portanto, também para Suárez, era um postulado objetivo, traduzia uma ordem natural pensada fora do quadro da conceção individualista dos estados, quer dizer, pensada em antinomia com uma conceção dos estados ou dos indivíduos tomados isoladamente, desligados de uma ordem mais vasta sem consideração da função que nela deveriam desempenhar ${ }^{2}$.

Aliás, o individualismo triunfante da tradição liberal, tanto na conceção dos estados como na do homem, como refere António M. Hespanha, sustentava-se na ideia de que "os vínculos e a disciplina sociais são factos artificiais", na medida em que se prescindia "da ideia de finalidade e de ordenação do homem para algo que o transcende" (Hespanha, 2015, p. 313), como seja a sociedade e a própria comunidade universal, fundadas no jus communicationis, que era um direito natural comum a todos os homens e comunidades humanas a nível planetário.

Quer isto dizer que, para Suárez, o fundamento da comunidade universal e os vínculos de solidariedade entre os estados eram anteriores ao jus gentium, na medida em que eram um postulado natural, correspondente a uma lei imanente de sociabilidade entre os povos, cabendo embora ao arbítrio e vontade dos estados integrarem-na, realizando assim, livremente, a sua natureza.

O jus communicationis, teorizado décadas antes por Francisco de Vitoria em Salamanca $^{3}$, radicado no direito natural, prolongava-se em Suárez nesta afirmação da lei imanente da sociabilidade, seja dos indivíduos seja dos estados, porque o mundo

natural estabelece que o poder político supremo segue-se naturalmente da comunidade humana perfeita, e que, por esse mesmo motivo, pertence a toda a comunidade" (Suárez, 1965, II, 8).

${ }^{2}$ Acompanhando de perto Francisco de Vitoria, escreveu o jesuíta Martín de Ledesma, nas suas lições de Coimbra, em 1560 : "Sendo uma república parte de todo o orbe e, maximamente, sendo uma província dos cristãos parte de toda a República cristã, se a guerra for útil a uma república ou reino em detrimento e com prejuízo de todo o orbe ou da Cristandade, eu considero que por isso mesmo ela é injusta", (Ledesma, 1560, p. 316). Martín de Ledesma, professor da Universidade de Coimbra entre os anos de 1540 e 1562 repete quase na íntegra, neste passo, idênticas palavras de Francisco de Vitoria na sua Relectio de Potestate Civili, Salamanca, 1527 (?), nº 28.

${ }^{3}$ Diz Francisco de Vitoria: "No princípio do mundo quando todas as coisas eram comuns, era lícito a qualquer um dirigir-se às regiões que entendesse e por elas peregrinar. E não consta que tal direito tenha sido anulado pela posterior divisão das coisas, pois nunca foi intenção das gentes impedir, por semelhante divisão, o trato e a comunicação entre os homens", (Vitoria, 1967, I, 3, I).

51 Pedro Calafate. A idea de Comunidade universal em Francisco Suárez ... 48-65. 
comportava em si mesmo uma ordem objetiva não meramente acidental ou puramente artificial, a qual se apresentava à vontade das criaturas livres como devendo ser observada.

Neste sentido, para Suárez, o jus gentium, na sua relação e harmonia com o direito natural ${ }^{4}$, regulando as relações entre os estados, não era um jus inteiramente interestatal em sentido estrito, ou estatocêntrico, na medida em que a soberania dos estados era considerada por Suárez como sendo relativa, por estar limitada pelo direito natural e pelo direito das gentes. Assim, a tese da soberania relativa dos estados, porque subordinados a uma ordem objetiva de valores, postulados pelos direitos natural e das gentes, ou seja, pela razão e vontade humanas, não acarretava antinomia entre a comunidade universal e os estados, cujo poder era "supremo na sua ordem ou matéria",5. Sublinha, com efeito, Francisco Suárez que "chama-se supremo aquele poder que na sua ordem ou matéria não está submetido a nenhum outro" (Suárez, 1965, V I, 2).

Dizer que a soberania dos estados é relativa e não absoluta significa que o soberano só tem poder para o que é justo e que para o que é injusto nenhum poder tem. O voluntarismo estatal ilimitado estava fora de causa, bem como a conceção de soberania expressa por Jean Bodin ou Maquiavel.

Dizer, por seu turno, que o estado é "supremo na sua ordem ou matéria" significa, em Suárez, perspetivá-lo na sua relação com o poder espiritual do papa. Quer dizer: nos assuntos que dizem respeito direta e principalmente ao fim temporal, o poder do estado cristão era supremo perante o papa. Mas o soberano cristão reconhecia uma autoridade na terra à qual se submetia em matérias do foro espiritual, acrescentando o jesuíta que o Papa, não tendo poder temporal, tinha, no entanto, poder sobre as coisas temporais, quando estava direta e principalmente em causa um fim espiritual. Tal poder indireto, sublinhe-se, não era poder temporal, pois derivava da eminência do fim espiritual do homem e, portanto, era constitutivo do poder espiritual do Papa. Voltaremos a este tema adiante, quando abordarmos a questão das soberanias dos estados não cristãos.

Em todo o caso, o importante a sublinhar no conceito de comunidade universal trabalhado pelos teólogos ibéricos do renascimento, sobretudo em Suárez, é que tal comunidade, de dimensões planetárias, abarcando por isso as novas regiões da América e África, tinha o seu fundamento na unidade do género humano e na natural sociabilidade entre os homens e não, como no período anterior, na autoridade do imperador ou no domínio universal do Papa. O seu fundamento era a razão natural dos homens -cujos princípios eram explicitados historicamente pelo jus gentium-, sendo que o qualificativo de "natural" apontava para uma dimensão constitutiva essencial, para uma ideia fundamental de universalidade, de ordem, de inteligibilidade e de racionalidade.

Por seu turno, tal comunicação e sociabilidade universais implicavam o reconhecimento dos direitos naturais de todos os indivíduos e de todos os povos, fosse

\footnotetext{
${ }^{4}$ Segundo Suárez, o direito natural "compreende princípios morais naturalmente evidentes e também todas as conclusões que derivam deles imediatamente, por ilação lógica ou através de sucessivos raciocínios", (Suárez, 1612, II, XIII, 3,4). Mais adiante acrescenta o jesuíta: "para distinguir o direito natural do direito das gentes é preciso que os seus preceitos se deduzam não como evidente consequência, mas através de deduções menos certas, de modo que dependam da livre vontade e da conveniência moral e menos da necessidade" (Suárez, 1612, II, XVII, 9).
} 
qual fosse a sua raça, formas de organização política ou coordenadas geográficas e culturais, dando assim guarida às diversidades culturais históricas, sem cair no relativismo.

Este era um dos princípios basilares desta tradição, vincando que não se podia separar a utilidade de um estado do bem comum universal, nem este podia ser entendido se não tivesse a sustenta-lo a dignidade da pessoa humana, que era, afinal, o seu próprio e mais digno fundamento. $O$ estado não era, então, um fim em si mesmo, mas uma entidade humana com fins humanos.

$\mathrm{Na}$ verdade, para Suárez, sendo o estado uma entidade social necessária, a pessoa humana tinha, não obstante, de considerar-se numa perspetiva que, na sua plenitude, superava o poder e a vontade dos soberanos.

Então, no tratado De legibus, publicado em Coimbra (1612), ensinou Suárez a respeito da comunidade universal que "todo o estado perfeito, república ou reino, ainda que completo em si e firmemente fundado é, todavia, ao mesmo tempo e duma certa maneira, membro deste universo, enquanto diz respeito ao género humano" (Suárez, 1612, II, 19, 9).

A exigência de consideração do plano universal e da consequente unidade e direitos do género humano como um todo, conduzia à necessidade de racionalizar a guerra, entendendo que a guerra não era um meio natural de resolução de conflitos e afirmando a paz como caracterização da vida.

Ou seja, nas matérias tão relevantes da paz e da guerra, não cumpria atender apenas ao interesse particular do estado, mas sim vincar a precedência e primazia ontológica da razão da humanidade sobre a razão de estado, do amor mútuo sobre a soberania e ainda da consciência sobre a vontade.

No entanto, enquanto os povos do orbe, cristãos ou não cristãos, não se unissem para reconhecerem uma autoridade arbitral suprema - que não o Papa ou o imperador romano-germânico que a não detinham -- o poder de castigar a injustiça de um estado contra outro residia no estado prejudicado, pois toda a pessoa, tanto privada como pública, tinha direito a rechaçar, por si mesma, um ataque ou ameaça à sua conservação, cabendo também às entidades coletivas como os estados, na fase histórica em que se encontrava a humanidade, o direito de conduzir uma guerra vindicativa a fim de castigar uma injúria grave, contra o que defendia Lutero e a quem Suárez explicitamente se opõe, neste domínio.

De facto, para Suárez a guerra, comportava duas espécies dentro do género comum: a guerra pelo direito de conservação do estado, que radicava no direito natural; a guerra ordinária, tanto defensiva como ofensiva, que radicava no direito das gentes e poderia ser suprimida ou transferida para a tutela futura da comunidade internacional, colocada, assim, debaixo da autoridade do direito das gentes, expressa de forma mais institucional e perfeita.

No entanto, no estado histórico em que se encontrava a humanidade, dada a ausência de tribunais internacionais com autoridade supraestatal, dotados de poderes punitivos e coercivos (Suárez, 1612, II, 19,4), vingava ainda o regime de autotutela. Mas, sublinhe-se mais uma vez, que, como refere H. Rommen (Rommen, 1951, p. 4912), Suárez dá a entender que este regime correspondia ao atual estado histórico da humanidade (século XVII) e que, na ordem do dever ser, a guerra deveria passar 
progressivamente para a esfera da autoridade universal do direito das gentes, tanto mais firme quanto mais vincado e afirmativo o compromisso e o consenso dos estados em torno das suas normas, não excluindo, pois, a constituição "de uma autoridade arbitral suprema [...] seja sob a forma de uma sociedade das nações seja sob outra considerada mais conveniente" (Rommen, 1951, p. 488).

Por outras palavras, como a comunidade universal, na sua plenitude, não estava ainda devidamente institucionalizada, em tais circunstâncias ela encarnava diretamente nos seus membros.

Diga-se, no entanto, que Suárez nem sempre foi muito claro a este respeito, deixando apenas entrever a desejável passagem da questão da guerra para a esfera de uma autoridade superior, de cariz internacional, em fase ulterior de desenvolvimento da comunidade dos estados, pois, enquanto tal fase não estivesse convenientemente estabelecida, o direito de conduzir a guerra ficava sob a alçada do estado prejudicado, ouvido o juízo dos prudentes. Já na esfera dos estados cristãos, Suárez defendeu claramente a autoridade indireta do Papa, que obrigava o príncipe cristão em consciência (e não apenas no âmbito do conselho ou súplica), na medida em que a guerra entre cristãos se opusesse ao fim espiritual da salvação.

Assim, para Suárez, a relação entre os estados do orbe era comandada pelo jus gentium, formulado em harmonia e proximidade com o direito natural, e encontrava no comum consentimento (virtual) das nações o fundamento da sua obrigatoriedade, expressão da pertença da pessoa humana a uma comunidade universal, regida por princípios de justiça, garantia da paz e das condições de conservação digna da vida, prolongando-se na teorização da noção de crime contra o género humano e da necessária defesa dos inocentes, sem atender a supostas imunidades estatais. Por isso, autonomizou a pessoa humana vis-a-vis o estado em que se integrava.

O mesmo Francisco Suárez, nessas suas lições de Coimbra, foi mais longe, explicando qual o fundamento antropológico deste princípio de humanidade: "Esta unidade é indicada pelo preceito natural do amor mútuo e da misericórdia, preceito que se estende a todos, mesmo aos estrangeiros, qualquer que seja a sua condição" (Suárez, 1612, XIX, 9).

Ou seja, aquele preceito estendia-se a todos, sem necessidade de vínculos de nacionalidade ou de vínculos estatais, ou ainda de normas humanitárias explicitas. A única condição era a pertença ao género humano, ficando, só por isso, sob a proteção e império do direito das gentes, porque os indivíduos não eram objeto de direitos que os estados eventualmente lhes concedessem, mas sujeitos dos quais emanavam diretamente direitos, cuja proteção estava não só sob a alçada do estado emergente, mas também da humanidade ou do conjunto das nações irmanadas num conceito de moralidade, assente em princípios de que não podíamos prescindir pelo facto de todos sermos humanos.

É sobre esta ideia de humanidade, pensada como princípio e instância que se sobrepõe à razão de estado, que se funda o preceito natural do amor mútuo, que na escola de ibérica da paz (Calafate, 2014; 2015) se prolongará no jus communicationis, no jus commercii e no jus amicitiae e, no contexto mais específico de um direito não estritamente natural, no jus praedicandi.

Neste contexto, em Suárez, a humanidade afirmava-se como um todo que se ramificava em diversos estados, expressão da tese da unidade do género humano, 
possibilitando a ideia de uma verdadeira comunidade de povos, regida pelo direito natural e pelo direito das gentes.

$\mathrm{Na}$ verdade, sendo os homens sociáveis por natureza, eles formavam comunidades políticas naturais, e, portanto, a cada povo correspondia a sua comunidade política que deveria perspetivar-se em função de uma unidade natural superior porque supraestatal: a comunidade dos povos da terra.

No entanto, assim como o estado não podia nem deveria absorver o indivíduo, porque a pessoa humana se perspetivava e fundamentava além e aquém das suas fronteiras - tornando relativa a soberania estatal --, também a comunidade universal não devia absorver os estados particulares, esmagando a soberania de cada um deles. Suárez, ao contrário do seu confrade jesuíta António Vieira (Vieira, 2014), não foi adepto do império universal, na medida em que este não era uma imposição nem do direito natural nem direito das gentes. No entanto, não deixava de sublinhar que os estados singulares não podiam ser entendidos fora de uma ordem universal objetiva ordenada a um fim, o bem comum, cujo conteúdo era a justiça como condição da paz.

Sobre esta recusa de um império ou estado universal diz Suárez que:

Em todo o orbe da terra não existe uma só república ou um só reino temporal, senão vários e muitos que não formam entre si um só corpo político, pois não foi conveniente que houvesse um só monarca nem um só governo [...] para todo o universo. Mais ainda, nem moral nem humanamente tal foi possível ${ }^{6}$.

A figura medieval do imperador é agora substituída pela autoridade universal do direito natural e pela autoridade "quase universal" do direito das gentes. Então, como sublinha H. Rommen (Rommen, 1958, p. 471), o direito das gentes e o direito natural tinham a humanidade como sujeito, mas o direito natural tinha a humanidade como sujeito mais diretamente como unidade composta por todos os homens. Já o direito das gentes tinha a humanidade como sujeito de forma indireta, pois a considerava tal como historicamente se apresentava, ou seja, dividida em Estados e, por isso, os estados eram os seus sujeitos diretos. Assim se configurava um jus gentium entendido como um jus intergentes, que, no entanto, não podemos identificar com um jus intergentes fragmentário protegido pelo consentimento dos mais poderosos. É um jus intergentes pensado em harmonia com o direito natural e, por isso, é antropocêntrico e não estatocêntrico.

Então, em Suárez, tal ordenamento a que a comunidade universal corresponde, não tinha, como dizíamos, o seu fundamento na observação da prática empírica dos estados, no direito ou na lei tal como ela é, a moderna "law as it is", a qual abriria as portas ao positivismo jurídico, nem era, uma mera forma subjetiva do entendimento que ordena autonomamente o mundo, o qual, em si próprio, seria uma espécie de caos. Para Suárez não cumpria ao jurista observar a prática dos estados mas dizer qual é o direito! Por isso, embora aberto à experiência histórica da diversidade dos povos e dos seus costumes, a doutrina de Suárez constitui um entrave ao positivismo e voluntarismo jurídicos.

Daí o seu importante texto ao clamar por um direito das gentes em harmonia com o direito natural, a fim de regular as relações entre os estados e dar expressão à comunicação e sociabilidade natural entre os homens e os povos ou nações:

\footnotetext{
${ }^{6}$ Suárez, 1965, VI, 10-11.
} 
As nações têm necessidade de um sistema de leis pelo qual possam dirigir-se e organizar-se devidamente nesta classe de intercâmbios e de mútua associação. E se bem que em grande parte esteja prevista pela razão natural, não o está, sem embargo, direta e plenamente em relação a todas as matérias e circunstâncias. Daí que possam estabelecer-se algumas leis especiais através dos costumes dessas mesmas nações. Porque da mesma maneira que num estado ou país o costume é fonte de direito, assim também na comunidade do género humano foi possível estabelecer leis internacionais por meio do costume. Sobretudo se se tiver em conta que são poucas as matérias que são objeto do direito das gentes e que estas são muito próximas do direito natural e podem ser deduzidas deste muito facilmente, e que são tão úteis e convenientes à mesma natureza dos homens que, sem chegarem a ser conclusões evidentes - absolutas e necessárias para a retidão moral - estão, não obstante, em plena harmonia com a natureza e podem ser facilmente aceites por todos ${ }^{7}$.

Em relação a Vitoria, como explica, por sua vez Truyol e Serra (Truyol e Serra, 1958, p. 131) Suárez abre mais o direito das gentes a uma relação fecunda com os costumes das nações, um direito das gentes costumeiro chamado a complementar o direito natural, em obediência à diversidade dos povos e suas experiências históricas, embora sem cair no voluntarismo ou no relativismo, não devendo esquecer-se que para o jesuíta, a razão e a vontade são dois momentos de um "mesmo processo escalonado e discursivo" (Suárez, 1612, I, IV, 6-7), permitindo-lhe conciliar o voluntarismo com a conceção objetiva e principista da justiça.

Então, salvaguardada a esfera do estado como comunidade autárquica dotada de elementos constitutivos que lhe são próprios, salvaguardada também a esfera do costume em harmonia com o direito natural e não o afrontando nos seus conteúdos fundamentais, salvaguardado o conceito de pessoa humana ou personalidade dotada valor anterior ao estado e limitador da sua soberania, podemos concluir que o principio de humanidade e a ideia de comunidade universal fundamentavam a paz, radicada na justiça, e que tanto a justiça como a paz, na sua relação causal, eram os dois pilares sobre que se ergueria o bem comum, como finalidade do poder civil.

\section{As soberanias dos estados não cristãos e a sua pertença à comunidade universal}

Partindo desta mesma ideia, um dos capítulos muito relevantes na obra de Suárez a respeito de noção de comunidade universal refere-se à forma como estes postulados se projetavam na reflexão sobre a experiência ultramarina dos portugueses e espanhóis, quer dizer, no cosmopolitismo emergente proporcionado pelos descobrimentos portugueses e pelas conquistas espanholas, embora Suárez, ao contrário de Vitoria e da primeira geração da Escola de Salamanca, quase nunca se lhes refira diretamente, preferindo uma argumentação metafísica. Embora tenha a América e a África em mente, assim como as vastas extensões do Oriente, Suárez raras vezes se refere a uma região ou povo em particular, falando sempre em cristãos, pagãos e infiéis (etnicos et infideles).

Trata-se, pois, da reflexão de Suárez sobre o estatuto dos estados não cristãos, na América, na África e no Oriente, membros da comunidade universal dos homens,

\footnotetext{
${ }^{7}$ Suárez, 1612, II, 19, 9.
} 
conduzindo a uma igualdade de natureza entre todas as soberanias do orbe, desde que estranhas ao conceito de tirania e suas espécies, limitando assim o poder do Papa e do imperador. Aqui radicava o moderno princípio da igualdade entre os estados, à luz da qual as disposições imperiais ou as diferenças de religião não podiam contrariar as disposições naturais radicadas na sociabilidade e racionalidade humanas.

Esta limitação do poder papal, conduzida por jesuítas e dominicanos das Universidades de Salamanca, Alcalá, Évora e Coimbra, exercia-se em plano de vincada adversidade, pois contra eles se levantava a tradição decretalista da teocracia. Era o caso, muito citado pelos jesuítas de Coimbra e Évora, do bispo de Silves do século XIV, Álvaro Pais, natural da Galiza, que apoiado no cardeal ostiense, Henrique de Susa, sustentava a tese de que o Papa era dominus orbis no temporal e no espiritual, na qual viria a basear-se uma ética colonial de conquista e subjugação dos gentios da América.

Álvaro Pais, tal como a maioria dos defensores da plenitudo potestatis papal dos séculos XIV e XV, tinham a seu favor a interpretação mais literal ${ }^{8}$ da Extravagante do Papa Bonifácio VIII, escrita em 1302, intitulada Unam sanctam, na qual sustentava que em poder de S. Pedro se encontravam os dois gládios (Luc 22, 38), razão por que em poder da igreja se encontravam a espada espiritual e a espada temporal.

Então, para Álvaro Pais:

O Papa tem jurisdição universal em todo o mundo, não só nas coisas espirituais, mas também nas temporais [...] porque assim como há um só Cristo, sacerdote e rei, senhor de todas as coisas, assim também há um só vigário-geral seu na terra e em tudo [...]. O Papa é vigário não dum puro homem mas de Deus [...]; logo, também pertencem ao Papa a terra e a sua plenitude <porque> Cristo concedeu os direitos dos dois poderes a S. Pedro'.

Em conformidade sustentava o bispo franciscano que: "Os reinos dos idólatras e pagãos que não prestavam verdadeiro culto a Deus, embora por eles ocupados, voltaram com razão para a Igreja [...], sobretudo depois que Cristo concedeu os direitos dos dois poderes a S. Pedro"

A enquadrar esta plenitude do poder papal estava a tese de que o poder político provém de Deus através do Papa, pelo que o poder do imperador e dos demais príncipes seculares era-lhes concedido diretamente pelo Pontífice Romano e não pelo povo, ao contrário do que defendiam Azpilcueta, Suárez e Molina e os demais autores jesuítas das universidades de Coimbra e Évora.

Já quanto a Henrique de Susa (ou Segusio), cardeal hostiense, em quem o autor galego se apoiava, sustentava que, com a vinda de Cristo, o poder temporal dos pagãos fora-lhes retirado e transferido para a o seu vigário e cabeça da Igreja, razão por que o domínio de jurisdição e propriedade entre os pagãos era de todo ilegítimo.

\footnotetext{
${ }^{8}$ Refiro a interpretação mais literal, pois os adversários da plenitude do poder papal interpretavam a mesma Extravagante de maneira diferente. Sirva de exemplo a belíssima Relectio, pronunciada pelo jesuíta Martin de Azpilcueta em 1548, perante a Assembleia da Universidade de Coimbra, no final do ano letivo, em que refere que o papa Bonifácio VIII queria apenas dizer que "o poder laico deve submeter-se ao espiritual quando o interesse das coisas sobrenaturais assim o exigir", in Relectio c. nouit de iudiciis, Conimbricae, 1548, edição de Calafate, Pedro, 2015, A Escola Ibérica da Paz nas Universidades de Coimbra e Évora. Coimbra, Portugal: Almedina, vol. II, p. 141.

${ }^{9}$ Pais, 1983, vol. I, pp. 347-45.

${ }^{10}$ Ibíd., p.1983, p. 348-349.
} 
Sublinhe-se, no entanto, que um dos momentos culminantes destas conceções, no final da idade média, foi a obra de Egídio Romano, intitulada De ecclesiastica sive de summi pontificis potestate ${ }^{11}$, escrita no início do século XIV, onde defende que foi o poder espiritual que instituiu o poder temporal, razão por que só os reinos que reconhecem o Papa como instituidor são legítimos.

Para Egídio, a verdadeira justiça, fundamento do poder político, só existe naquela república cujo fundador e governador é Cristo, mas nada está sob o governo de Cristo se não estiver sob o Sumo Pontífice que é vigário de Cristo. Logo, os povos que não reconhecem a autoridade do Sumo Pontífice não são legítimos possuidores dos seus bens nem os seus reis legítimos governantes. Só pelo batismo o homem pode possuir legítimo domínio e por isso os infiéis não são legítimos possuidores.

Suárez rejeita tais conceções em toda a linha. A respeito das soberanias e territórios não cristãos o Papa possuía apenas o direito de enviar pregadores, com base nos textos dos Evangelhos de São João $(10,16)$ e de S. Marcos $(16,15)$. Esse era o fundamento do jus praedicandi.

Queria isto dizer que o Papa poderia conceder esse direito, mediante opção preferente, a algum rei ou príncipe cristão em detrimento dos demais, porque o Papa tinha poder sobre os príncipes cristãos em matérias do foro espiritual, como era o caso da pregação, e tinha poder indireto sobre as coisas temporais quando estivesse direta e principalmente em causa um fim espiritual, ou seja, podia reservar o jus commercii nas regiões a evangelizar aos príncipes a quem concedeu essa missão, pois se tratava de um comércio que visava sustentar economicamente o fim espiritual da pregação. Por isso, conclui Suárez, a respeito do tratado de Tordesillas (1494):

Assim fez Alexandre VI com os reis de Espanha e Portugal. O motivo pelo qual o fez é claro: traz muita utilidade à regência da igreja e à paz porque o Pontífice pode proibir e delegar o seu direito a quem lhe aprouver ${ }^{12}$.

Mas isso não queria dizer que o Papa tivesse poder algum espiritual ou temporal (direto ou indireto) sobre os índios ou gentios que não eram seus súbditos pelo batismo, nos termos sempre citados do apóstolo Paulo: "Como posso julgar os que estão de fora?" (I Cor 6, 14). Daí que não os pudesse obrigar à conversão nem castigar pelo pecado de infidelidade. Nos mesmos termos não os podia privar do domínio de jurisdição e propriedade, nem tão pouco do poder de jurisdição que eventualmente tivessem sobre os cristãos.

As afirmações de Suárez a este respeito são muito contundentes, começando por vincar que o poder temporal não dependia da fé, mas da razão natural, razão por que critica as teses de Álvaro Pais e de Henrique de Susa a que acima já fizemos referência:

A própria razão natural estabelece que o poder político supremo segue-se naturalmente da comunidade humana perfeita" sendo que "a comunidade civil perfeita é livre por direito natural e não está sujeita a homem algum fora de si, mas detém em si, na verdade, toda ela o poder, o qual é democrático conquanto não mude (Suárez, 1612, II, 8).

\footnotetext{
${ }^{11}$ Existe desta obra uma excelente tradução em língua portuguesa: Egídio Romano, 1989, Sobre o Poder Eclesiástico, trad. L.A. De Boni, Petropolis, Brasil: Vozes..

${ }^{12}$ Francisco Suárez, sd, De mediis quibus infidelis possint licite ab hominibus ad fidem adducit, Roma Universidade Gregoriana, ms. 452, quaestio $4^{\mathrm{a}}$.
} 
Esta fora já a lição do jesuíta Luis de Molina em Évora, na década de 70 do século XVI, no seu De iustitia et iure, ao escrever: "Pelo simples facto de os homens terem concordado em constituir o corpo do estado, nasce por direito natural o poder deste estado sobre os seus membros para seu governo, legislação, administração da justiça e castigo"13.

E fora também, antes de Molina e Suárez, a lição do jesuíta Martín de Azpilcueta em Coimbra, em 1548, quando, perante a assembleia magna daquela Universidade portuguesa cita concordantemente o pensamento de Baldo:

Quando os povos não têm a luz e o apoio de um imperador, é mister que sejam para si a sua própria luz, e quem não tem guia e chefe, é o seu próprio chefe e guia. Não vai em sentido contrário o facto de que muitos povos parecem carecer completamente de jurisdição. $\mathrm{Na}$ verdade, não carecem completamente de jurisdição mas do seu uso ${ }^{14^{3}}$.

Por isso, Martín de Azpilcueta parte diretamente para a crítica a Álvaro Pais:

Erra Álvaro Pais, pois ampliando o poder papal, diz que os idólatras e pagãos jamais tiveram jurisdição alguma e, por isso, todos os seus reinos pertencem à Igreja cristã e, por consequência, ao Papa, que se encontra à frente da mesma. Este erro foi a causa de que, na nossa época, muitos povos do Novo Mundo tivessem sido despojados dos seus domínios ${ }^{15}$.

Neste ponto, tanto Suárez como Azpilcueta e Molina e, em geral, os teólogosjuristas da Companhia de Jesus, seguiam a lição de Tomás de Aquino, para quem a distinção entre fiéis e infiéis, em si mesma considerada, não suprimia o direito humano, razão pela qual a distinção entre cristãos e não cristãos não poderia suprimir o direito ao domínio de jurisdição e propriedade, constitutivo de todas as comunidades humanas naturalmente constituídas. No fundo, como explicava ainda São Tomás, a graça não suprime ou contradiz a natureza mas aperfeiçoa-a.

É por isso que Suárez ensinava, no seu tratado De legibus, que :"Tudo o que foi dito até agora sobre o poder natural que têm os homens para ditar leis civis é universalmente válido para todos os pagãos e infiéis" (Suárez, 1612, III, V, I), rematando de seguida um princípio universal: "O poder dos príncipes cristãos, em si mesmo, não é de maior nem de distinta natureza que o poder dos príncipes pagãos; logo, em si próprio, não tem outra matéria nem outro fim" (Suárez, 1612, III, V, 12).

A estas considerações de princípio importava acrescentar a tese de que os pagãos podiam ser verdadeiros reis, inclusive reis dos cristãos, "como homens que são, ainda que não possuam uma alma reta" (Suárez, 1965, III, 4), tendo o cuidado de responder ao argumento contrário fundado nas palavras de São Paulo "Não vos deixeis conduzir sob o jugo dos infiéis" (2 Cor 6, 14), com o argumento de que que São Paulo apenas quis dizer que "não devemos tomar parte das ações dos infiéis enquanto infiéis" (Suárez, 1965, IV, 19), excluindo, pois, o domínio político dos pagãos sobre os cristãos.

\footnotetext{
${ }^{13}$ Molina, 1593, tomo I, liv. I, disp. XXII.

${ }^{14}$ Azpilcueta, 1548, fol. 74, Seguimos a edição moderna de Pedro Calafate, 2015, A Escola Ibérica da Paz nas Universidades de Coimbra e Évora. Coimbra, Portugal: Almedina, vol. II, p. 106.

${ }^{15}$ Ibid., pp. 84-85.
} 
A estas postulações sobre a igualdade natural entre as soberanias do orbe acrescia outra não menos relevante que estabeleceu no seu tratado sobre a guerra: os princípios naturais que legitimam a guerra (justa) são iguais para pagãos e cristãos: "Os príncipes cristãos não têm nenhum título especial para fazer uma guerra justa que não esteja baseado de algum modo na lei natural ou relacionado com ela e que, por conseguinte, não corresponda também aos príncipes pagãos "16.

Assim, a ideia de comunidade universal sustinha também a igualdade natural entre o conjunto das soberanias do orbe, fosse na Europa fosse na América ou em quaisquer outras regiões do orbe, independentemente das suas múltiplas formas de organização política e económica.

Ainda assim, a este respeito da igualdade natural entre as soberanias, ouso dizer que um dos mais belos textos proferidos por um antigo jesuíta do mundo iberoamericano, em conformidade com estes ensinamentos de Suárez e da tradição tomista ibérica, foi o do Padre António Vieira, no seu Voto sobre as Dúvidas dos Moradores de São Paulo (1694), que nunca é de mais citar, por constituir digna moldura retórica dos princípios que vimos enunciando. Pensando na escravatura a que haviam sido submetidos os índios de São Paulo (Brasil), remata:

Assim como o espanhol ou genovês cativo em Argel é contudo vassalo do seu rei e da sua república, assim o não deixa de ser o índio, posto que forçado e cativo, como membro que é do corpo e cabeça política da sua nação, importando igualmente para a soberania e a liberdade, tanto a coroa de penas como a de ouro e tanto o arco como o cetro. ${ }^{17}$

\section{O direito de intervenção do papa na esfera dos estados não cristãos}

Deve, no entanto, referir-se que Francisco Suárez não se quedou pelos estritos limites da laicização do direito das gentes, ao equacionar a relação entre os estados cristãos e não cristãos, na medida em que abriu espaço para a intervenção do Papa e dos príncipes cristãos na órbita das soberanias indígenas em determinados casos, muito específicos.

Suárez não prescindiu da fé na sua consideração do mundo e da finalidade da vida humana. O seu pensamento universalista estava ancorado no cristianismo, nomeadamente no modo como considerou serem mais perfeitos os reinos dos príncipes cristãos do que os dos pagãos, por via do auxilio da graça, embora no plano da natureza devessem considerar-se em plano de igualdade. Foi, pois, o reconhecimento dessa hierarquia que lhe permitiu fazer algumas considerações que aqui enunciaremos.

De facto, considerou que, apesar de os pagãos poderem ser reis dos cristãos, ainda que não possuíssem uma alma reta, caso o Sumo Pontífice entendesse que tais príncipes atuavam de modo a porem claramente em causa a salvação das almas dos súbitos cristãos, a igreja poderia, no limite, isenta-los de obediência, extraindo-os à autoridade de tais príncipes. No fundo, a igreja podia livrar e defender os seus súbditos espirituais dos perigos morais que se constituíssem em ocasião para a perdição das almas e da fé, embora não tivesse jurisdição temporal nem espiritual sobre os príncipes

\footnotetext{
${ }^{16}$ Suárez, De bello, sect. 5, n. 6, Apud. Rommen, 1951, p. 497-8.

${ }^{17}$ Vieira, 2014, p. 276.
} 
pagãos. Nestes casos a Igreja podia agir apenas em virtude do governo espiritual dos cristãos, que lhe competia, ou seja, em virtude da necessária providência sobre os seus fiéis súbditos.

Portanto, a igreja podia isentar os cristãos da obediência aos príncipes pagãos caso se temesse "perigo geral e comum" (Suáre, 1965, IV, 9-10), moralmente falando. No entanto, o jesuíta entende que, embora o Papa possua tal direito, ele só deve ser exercido em casos extremos, pois, nem tudo o que era lícito poderia entender-se como conveniente, atendendo às razões do escândalo e às dificuldades que a partir daí se colocariam na relação entre cristãos e pagãos.

Do mesmo modo e em virtude do mesmo princípio, caso um príncipe pagão impedisse, pela força, a livre e voluntária conversão dos seus súbditos ao cristianismo, tal impedimento transformá-lo-ia em tirano, podendo o papa recorrer ao auxílio dos príncipes cristãos para mover guerra justa em "defesa dos inocentes", à luz do conceito de resistência ativa à tirania. Os infiéis e pagãos tinham o direito de aceitar livremente a conversão ao cristianismo, impedi-los de se converterem livremente ao cristianismo ou convertê-los ao cristianismo pela força e pelo medo, afrontando a liberdade, eram crimes que Suárez situava no mesmo plano.

Em contexto próximo, cabendo ao papa o direito/dever de predicar o Evangelho, se uma parte da república impedisse a pregação dos cristãos, teriam estes o direito de presumir que a outra parte poderia estar interessada em ouvir. Neste caso, justificava-se a guerra contra quem obstaculizasse pela força a pregação. Mas se fosse toda a república pagã a manifestar a sua oposição, a guerra não se justificava, pois ninguém poderia ser obrigado a ouvir a pregação e muito menos a converter-se.

O fator religioso volta a manifestar-se quando equaciona outro caso: era verdade que os súbditos de um príncipe pagão, recentemente convertidos ao cristianismo, deviam-lhe obediência, caso se não manifestassem os perigos acima enunciados. Era também verdade que os pagãos podiam ser legítimos reis dos cristãos. No entanto, à luz da sua tese sobre a soberania inicial do povo, em se entretanto de eleger ou escolher livremente um novo príncipe, a preferência dos súbditos cristãos deveria incidir, por norma, sobre um cristão em detrimento de um pagão, pois podiam temer-se, "com probabilidade", os escândalos e perigos adveniente para os fiéis, devido à eleição de um príncipe não cristão, não submetido diretamente à autoridade espiritual do Papa, bem como ao seu poder indireto sobre as coisas temporais em ordem ao fim espiritual.

\section{Conclusão: sobre a relevância atual de Francisco Suárez}

Suárez escreveu em contexto de crítica à contrareforma e parte substancial da sua motivação intelectual visava o restabelecimento da unidade cristã. Por isso, a atmosfera religiosa em que se moveu marcou seguramente o seu pensamento nos planos jurídico-político, pois o cristianismo definiu, desde sempre, a sua opção pela verdade, na mesma medida que lhe permitiu estruturar a sua visão do mundo.

Mas tal não obstou a que, dentro desse mesmo contexto, se preocupasse com a teorização da autonomia da razão natural na esfera temporal e civil da vida humana, sem olvidar a sua relação "extrínseca" com o horizonte intemporal da salvação. Para 
tanto, inspirou-se no preceito ciceroniano da recta ratio ${ }^{18}$, de modo a alargar ao conjunto dos povos um acervo de regras de direito natural e das gentes capaz de constituir uma base sólida para a convivência humana num mundo cada vez mais marcado pela diversidade de crenças religiosas e costumes particulares dos grupos. Assim se lançariam as bases da justiça e paz como garantias do bem comum, sob a égide de uma razão da humanidade que se sobrepunha à razão de estado e à dimensão estritamente internacional (intergentes) do direito. É aí que ganha todo o sentido o seu conceito de comunidade universal de natureza supraestatal, vincando a possibilidade de conciliar a realidade das diversidades culturais dos povos com a universalidade de obrigações e direitos inerentes a todos os seres humanos.

De facto, esta luta por um direito natural válido para todos os tempos e lugares, enriquecido pelo direito das gentes, de modo a abranger o plano não apenas da necessidade e da evidência que caracterizava o direito natural, mas também o da livre vontade e da conveniência moral, através de "deduções menos certas" (Suárez, 1612, II, XVII, 9) -abrindo o espaço necessário para as diversidades culturais e históricas dos povos- onde o direito das gentes se movia, foi seguramente uma contribuição decisiva para o moderno Direito Internacional dos Direitos Humanos, tal como se foi estruturando e afirmando, desde o final da II Guerra Mundial aos nossos dias. Aí reside a fecundidade permanente das ideias ensinadas por Suárez em Coimbra.

$\mathrm{Na}$ verdade, uma das marcas mais características do Direito Internacional dos Direitos Humanos na atualidade é a de, no dizer de Antônio Cançado Trindade, "não visualizar a humanidade como sujeito de direito a partir da ótica do Estado; reconhecendo antes os limites do estado a partir da ótica da humanidade" (Trindade, 2006, p. 408).

Se desde os séculos XVII e XVIII a ideia de direitos humanos inalienáveis se foi firmando na ótica essencialmente do direito interno estatal, sobretudo no âmbito do direito constitucional (Trindade, 2003, p. 35), tal não se verificou ao nível do direito internacional clássico, onde continuou a prevalecer a abordagem estatocêntrica (Guerra, 2013, p. 89), que no início deste artigo procurámos caracterizar. Nessa linha de afirmação da primazia da soberania dos estados, considerados sujeitos únicos do direito internacional, a subjetividade internacional da pessoa humana e das comunidades não organizadas em estados, como sucede com a problemática atual dos povos indígenas ${ }^{19}$ no continente americano, fica fragilizada.

Foi a partir da vocação universal da Declaração das Nações Unidas de 1948 que se passou a impor, no século XX e num caminho difícil e cheio de retrocessos, a ideia já defendida por Suárez de que prevalecem normas sobre o ser humano e a sua natureza social que antecedem os direitos dos estados, pelo que a pessoa humana e as comunidades coletivamente consideradas têm que considerar-se como sujeitos de direitos que deles emanam diretamente e não como objetos de direitos que as soberanias estatais lhes reconhecem, quer dizer, o indivíduo e as comunidades humanas

\footnotetext{
18 "O verdadeiro direito é a recta ratio em conformidade com a natureza; é de aplicação universal, inalterável e perene [...] um direito eterno e imutável [...] válido para todas as nações em todos os tempos" Cícero, De Republica, liv. III, cap. XXII, parágrafo 33.

${ }^{19}$ Cf., Loureiro, Sílvia, 2015, A Reconstrução da Subjetividade Coletiva dos Povos Indígenas no Direito Internacional dos Direitos Humanos. O Resgate da Escola Ibérica da Paz (séculos XVI e XVII) em Prol de um Novo Jus Gentium para o Século XXI. Dissertação de doutoramento, PUC-Rio de Janeiro, Prémio Capes-Tese/Direito, 2016.
}

62 Pedro Calafate. A idea de Comunidade universal em Francisco Suárez ... 48-65. 
organizadas em moldes diferentes das soberanias estatais europeias não são meros objetos da regra jurídica mas seus sujeitos.

Daí até à emergência recente da noção de jus cogens, sobretudo a partir da Convenção de Viena sobre o Direito dos Tratados (1968-9), proclamando a existência de disposições convencionais de vocação universal que os estados não podem por si sós derrogar, por serem hierarquicamente superiores às normas dispositivas inerentes às suas soberanias (Brotóns, 2007 p. 69), assinalou-se uma conquista decisiva para a qual Suárez havia já certamente contribuído: a ideia de que tais normas imperativas se fundam na consciência jurídica universal (recta ratio) e na consciência jurídica dos estados não isoladamente considerados, mas alçados a uma ordem superior de desígnios comuns, quer dizer, de valores da comunidade universal, de que emergem obrigações erga omnes (a cargo de todos) e não apenas inter partes (condicionadas à regra da reciprocidade).

Esta situação acabou por configurar um regresso do direito natural e, de certo modo, "uma assunção reciclada da "auctoritas totius orbis" a que se referiu Francisco de Vitoria no século XVI (Vitoria, 2008, p. 63) e que Suárez aprofundou no início do século XVII.

E como, nos nossos dias e a despeito da ONU, nenhum estado em particular pode dizer quais são as normas imperativas que formam o jus cogens, pressupõe-se por uma opinio iuris cogentes apreciada em função de juízos de valor amplamente compartilhados pelo conjunto ou pela maior parte dos estados, como Suárez propunha a respeito do seu conceito de jus gentium em harmonia com o direito natural: um direito das gentes que deriva da "comum estimação dos homens" (Suárez, 1612, II, XIX, 5-5), conciliando assim o voluntarismo e o objetivismo ético, pois que o jesuíta nunca foi um voluntarista no sentido estrito. Para ele, como já dissemos, a razão e a vontade eram fases de um mesmo processo discursivo.

Faz, pois, todo o sentido que terminemos este nosso estudo citando as palavras de Antônio Cançado Trindade, ex-presidente da Corte Interamericana de Direitos Humanos (CiADH), a respeito do que chama o Direito Internacional da Humanidade, recebido como herança fundamental dos "pais fundadores" que, nas universidades ibéricas dos séculos XVI e XVII, ergueram as bases que agora se trata de enriquecer em novos moldes e à luz dos desafios contemporâneos:

Toda esta evolução conceitual tem gradualmente se movido, nos últimos anos, da dimensão internacional à propriamente universal [...]. O reconhecimento de certos valores fundamentais, com base em um sentido de justiça objetiva, tem em muito contribuído à formação da communis opinio juris nas últimas décadas do século XX e início do XXI [...]. Em suma, já não se sustenta o monopólio estatal da titularidade de direitos no plano internacional, tendo-se consolidado a emancipação da pessoa humana vis-a-vis o próprio Estado [...]. Na medida em que se estender ao reconhecimento dos valores universais, a comunidade internacional se moverá do jus intergentes ao novo jus gentium, o direito internacional da humanidade. ${ }^{20}$

\footnotetext{
${ }^{20}$ Cançado Trindade, António, 2006, "Memorial por um novo Jus Gentium, O Direito Internacional da Humanidade", in Op. cit., p. 403-406.
} 
Passados, este ano de 2017, quatrocentos anos sobre a sua morte, estas palavras, embora não se lhe refiram diretamente, são justo motivo de homenagem ao eminente jesuíta que pensou a paz entre os povos do mundo a partir das suas cátedras de Salamanca e Coimbra, nos séculos XVI e XVII.

\section{Referências Bibliográficas}

Arendt, H. (2011). As Origens do Totalitarismo. tradução de Roberto Raposo, $5^{\mathrm{a}}$ edição. Lisboa, Portugal: Dom Quixote.

Azpilcueta, M. de (1548). Relectio C. Novit de Iudiciis.... Coimbra, Portugal: Ioannes Berrerius. (Seguimos a edição moderna de Pedro Calafate, 2015, A Escola Ibérica da Paz nas Universidades de Coimbra e Évora. Coimbra, Portugal: Almedina, vol. II, pp. 23 a 192).

Brotóns, A. R. (2007). Derecho Internacional. Valencia, España: Tirant lo Balnch.

Calafate, P. e Gutiérrez, R. (2014). Escuela Ibérica de la Paz: la conciencia crítica de la conquista y colonización de América. Santander, España: Editora Universidade de Cantabria.

Calafate, P. (2015). A Escola Ibérica da Paz nas Universidades de Coimbra e Évora. Coimbra, Portugal: Almedina, volumes I e II.

Cançado Trindade, A. (2006). "Memorial para um novo jus gentium, o Direito Internacional da Humanidade". En: A Humanização do Direito Internacional. Belo Horizonte, Brasil: Delrey.

(2003). Tratado de Direito Internacional dos Direitos Humanos. Porto Alegre, Brasil: Sérgio Antônio Fabris.

Egídio Romano (1989). Sobre o Poder Eclesiástico. Tradução. L.A. De Boni, Petropolis, Brasil: Vozes.

Guerra Martins, A. M. (2013). Direito Internacional dos Direitos Humanos. Coimbra, Portugal: Almedina.

Hespanha, A. M. (2015). Cultura Jurídica Europeia: síntese de um milénio. Coimbra, Portugal: Almedina.

Loureiro, S. (2015). A Reconstrução da Subjetividade Coletiva dos Povos Indígenas no Direito Internacional dos Direitos Humanos. O Resgate da Escola Ibérica da Paz (séculos XVI e XVII) em Prol de um Novo Jus Gentium para o Século XXI. Dissertação de doutoramento, PUC-Rio de Janeiro, Brasil. Prémio CapesTese/Direito, 2016.

Martín de Ledesma (1560). Secunda Quartae. Coimbra, Portugal: Ioannes Aluarus.

Molina, L. de (1593). De Iustitia et Iure. Cuenca, Espanha tomo I, liv. I.

Pais, Á. (1983). De Status et Planctu Ecclesiae. Lisboa, Portugal : INIC, vol. I.

Rommen, H. (1951). La Teoria del Estado y de la Comunidad Internacional em Francisco Suárez. Buenos Aires, Argentina / Madrid, Espanha: Facultad de Derecho y Ciencias Sociales e Instituto Francisco de Vitoria/ CSIC. 
Suárez, F. (1612). Tractatus de Legibus ac Deo Legislator. Coimbra, Portugal: apud Alphonsum Furtado de Mendonça.

(1965). Defensio Fidei Catholicae... III. Principatus Politicus. Corpus Hispanorum de Pace, dir. Luciano Pereña e E. Eleoduy, Madrid, Espanha: CSIC, vol. II.

(1978). De Iuramento Fidelitatis. Corpos Hispanorum de Pace, vol. XIX, dir. L. Pereña, V. Abril y C. Baciero, Madrid, Espanha: CSIC.

Truyol y Serra, A. (1958). Genèse et Fondements Spirituels de l'Idée d' une Communauté Universelle. Lisboa, Portugal: Faculdade de Direito da Universidade de Lisboa.

Vieira, A. (2014), Obra Completa do padre António Vieira. Direção de José E. Franco e Pedro Calafate, Lisboa, Portugal: Círculo de Leitores, Tomo IV, volume III: Escritos sobre os Índios.

(2014), Obra Completa do Padre António Vieira, Dir. José Eduardo Franco e Pedro Calafate, Tomo III, volume I, Círculo de Leitores, Lisboa.

Vitoria, F. de (1967). Relectio de Indis. Direção de Luciano Pereña, Corpus Hispanorum de Pace, Madrid, Espanha: CSIC, vol. V.

(2008), Relectio de Potestate Civili, Corpus Hispanorum de Pace, Segunda Série, ed. de Jesús Cordero Pando, Madrid, Espanha: CSIC. 